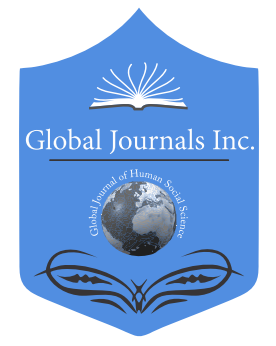

GLOBAL JOURNAL OF HUMAN-SOCIAL SCIENCE: B

GeOGRAPHY, GEO-SCIENCES, ENVIRONMENTAL SCIENCE \& DisASTER MANAGEMENT

Volume 21 Issue 3 Version 1.0 Year 2021

Type: Double Blind Peer Reviewed International Research Journal

Publisher: Global Journals

Online ISSN: 2249-460X \& Print ISSN: 0975-587X

\title{
Public Energy Management and Decision- Making Model: A Proposal based on Energy Sustainability Indicators
}

By Fabricio Quadros Borges, Fabrini Quadros Borges \& Mario Rocha de Vasconcelos

Universidade do Estado do Pará

Abstract- The objective of this study is to develop a decision-making model for the Brazilian electricity sector, based on sectoral indicators of energy sustainability. The methodology of this investigation constructed sectorial indicators of energy sustainability, from linear correlations verified between variables of the energy input and development variables, whose results fed a decision-making structure supported by technology, norms and rules and in the decision style. The place of study was the State of Pará and the time span between 2010 and 2019. The investigation concluded the need to re-read the decision-making process in the Brazilian electricity sector, through the essential use of a sectorial system of indicators, which demonstrates strategic respect for the specificities the economic sectors and to guide, through a decision-making model, how electricity can be translated into development based on the productive processes of these sectors.

Keywords: electric energy. investments. economic sectors.

GJHSS-B Classification: FOR Code: 280109

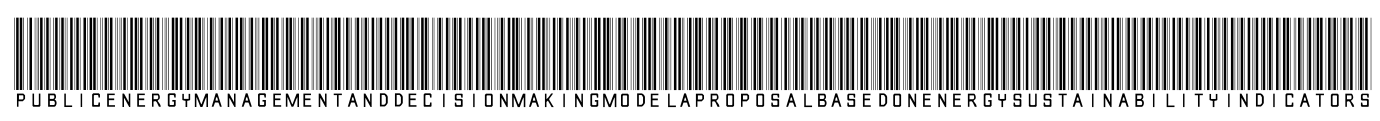

Strictly as per the compliance and regulations of:

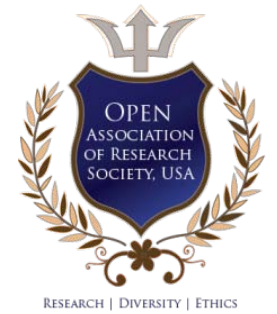

(c) 2021. Fabricio Quadros Borges, Fabrini Quadros Borges \& Mario Rocha de Vasconcelos. This research/review article is distributed under the terms of the Attribution-NonCommercial-NoDerivatives 4.0 International (CC BY-NC-ND 4.0). You must give appropriate credit to authors and reference this article if parts of the article are reproduced in any manner. Applicable licensing terms are at https://creativecommons.org/licenses/by-nc-nd/4.0/. 


\title{
Public Energy Management and Decision- Making Model: A Proposal based on Energy Sustainability Indicators
}

\author{
Fabricio Quadros Borges ${ }^{\alpha}$, Fabrini Quadros Borges ${ }^{\circ} \&$ Mario Rocha de Vasconcelos ${ }^{\rho}$
}

\begin{abstract}
The objective of this study is to develop a decisionmaking model for the Brazilian electricity sector, based on sectoral indicators of energy sustainability. The methodology of this investigation constructed sectorial indicators of energy sustainability, from linear correlations verified between variables of the energy input and development variables, whose results fed a decision-making structure supported by technology, norms and rules and in the decision style. The place of study was the State of Pará and the time span between 2010 and 2019. The investigation concluded the need to re-read the decision-making process in the Brazilian electricity sector, through the essential use of a sectorial system of indicators, which demonstrates strategic respect for the specificities the economic sectors and to guide, through a decision-making model, how electricity can be translated into development based on the productive processes of these sectors. This study, which presents a suggestion for this system of indicators and can be applied to any Brazilian state, points out that public actions in Pará should promote an increase in energy autonomy, redirection of the industrial profile, inclusion of compensatory devices for environmental costs and targeting from strategic investments to the increase of Gross Intensive Product.
\end{abstract}

Keywords: electric energy. investments. economic sectors.

\section{INTRODUCTION}

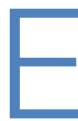
lectricity public management and decision-making aspects in the electricity sector have always been prominent in the social debate. Modern society uses increasing amounts of electricity (Narayan, Doytch, 2017). Electric energy has always been a fundamental bias in the development process of societies (Collaco et al., 2019). According to Schultz (2016) and Pereira (2018), public management encompasses intricacies linked to the territory and the needs of populations, in order to also involve connections between economic, social and political powers, through decision-making.

The electricity sector is a social organization formed by systemic relationships that involve the process of transforming primary energy to its finais use by type of consumer. These relationships are established between the components of the electricity sector, such as: generation, transmission and distribution of electricity. Electric energy is a secondary

Author a p: Instituto Federal do Pará, Brasil.

e-mail:posdoctorborges@gmail.com

Author o: Universidade do Estado do Pará, Brasil. energy that can be acquired through primary energy sources transformed from converters; however, depending on the nature of these converters, the generation of electricity can direct economic, social, technological and environmental impacts, to a greater or lesser extent, from all sectors of economic activity (Reis, Fadigas, Carvalho, 2012). The quantitative and qualitative profile of the availability of the energy input establishes bases for the conditions of the populations to guarantee a certain quality of life through. It is in this sense that the construction of electricity sustainability indicators represents relevant tools in view of the possibility of unraveling the existing intricacies between electricity and quality of life.

According to Borges (2012), in public electricity management, indicators favor the decision-making process through guidelines, which tend to articulate with greater precision the strategic mission of energy with the development of regions and countries. In each economic segment, electricity reflects in order to generate jobs, levels of income concentration, consumption flow, volumes of polluting gases emitted, from different quantities. (Amaral, 2017). In this perspective, this study asks: how could decision-making in the electricity sector in Brazil be supported by sectorial indicators of energy sustainability? The purpose of this investigation is to build a decision model for the electric energy sector in the country, supported by sectorial indicators of electric energy sustainability.

\section{TheOretical FrameWOrK}

The discussion environment about public management has raised numerous relevant aspects for examining the capacity of public managers to achieve efficient goals in dealing with public resources invested in regions or countries; among these aspects, it is cited the interference of the ideological field of people who influence more decisively with the decision-making power, through relations in segments, such as electricity among them, the influence of ideologies of groups that interfere with more power of decision, through correlations of forces along various branches, such as energy (Schultz, 2016).

The public energy management environment is developed through public policies in the electricity 
sector, which generally aim to demonstrate that investments aim at economic growth and improving the population's living conditions. In this process, strategic aspects are verified, from the choice of electricity generation sources to the effects of the use of this energy in the different sectors of a country's economy (Bermann, 2003; Borges 2012; Cornescu, Adam, 2014).

As for decision-making in the public environment, according to Silva (2013), there are three elements that make up a decision-making process within public management. They are: technology; rules and norms; and decision-making style. With regard to technology, it is observed that the administrative and organizational structure must be improved from instruments relevant to information technology to support decision-making, as a way of reducing risks, that is, without using aspects of a subjective nature; as for the rules and norms, it is highlighted that the obedience to these norms and rules makes it possible to achieve optimization in decision making; and finally, with regard to the decision-making style, it is highlighted that it refers to the common standards that decision makers tend to use when facing a decision-making panorama (Silva, 2013).

In this perspective of discussion, attention is drawn to the mission of electricity sustainability indicators in line with the intricacies of the decisionmaking process. Indicators must be interpreted based on the definition of sustainable development. Sustainable development seeks sustainability and the difficulties in conceptualizing the terminology sustainability demonstrates the difficult task of reflecting concepts in practical terms (Sachs, 2009; Costa, Teodósio, 2011; Prado, 2015). According to Costa and Teodósio (2011), sustainability comprises the ability to maintain bases of an economic, social and environmental nature that generate the possibility of contemplating the demands of populations in a harmonious way and the organized possibility of examining sustainability is in line with the elaboration of sustainability indicators.

The effort to improve energy analysis tools along with the development process has translated since the 1990s into three important contributions. The indicators from Helio Internacional, the indicators from the National Electric Energy Agency - Aneel and the indicators from Camargo et al. (2004). The indicators of Helio International (2005) are composed of eight indicators, divided into four aspects: economic, environmental, social and technological. The indicators from Aneel (1999) punctuated the ecological, political, economic and technological aspects. And finally, the indicators by Camargo et al. (2004) were composed in economic, environmental and social indicators.

\section{ili. Methodological Strategy}

The study site was the State of Pará. Pará comprises a geographical area of $1,247,689.515 \mathrm{~km}^{2}$ and an estimated population of 8,690,745 inhabitants, which gives it a density of 6.96 inhabitants $/ \mathrm{km}^{2}$ (lbge, 2020). The public electricity distribution service in the State is a concession of Centrais Elétricas do Pará Celpa, while the share in the generation market is the domain of Centrais Elétricas do Norte - Eletronorte.

The correlation sought as a result a coefficient that quantified the degree of correlation Pearson's coefficient (p) (Chen, Popovic, 2002).

$$
r=\frac{\sum_{i=1}^{n}\left(x_{i}-\bar{x}\right)\left(y_{i}-\bar{y}\right)}{\sqrt{\sum_{i=1}^{n}\left(x_{i}-\bar{x}\right)^{2}} \cdot \sqrt{\sum_{i=1}^{n}\left(y_{i}-\bar{y}\right)^{2}}},
$$

Where: $x 1, x 2, \ldots, x n$ and $y 1, y 2, \ldots, y n$ comprise the measured values of both variables. And the following equations are the arithmetic means of these variables:

$$
\bar{x}=\frac{1}{n} \cdot \sum_{i=1}^{n} x_{i} \quad \bar{y}=\frac{1}{n} \cdot \sum_{i=1}^{n} y_{i}
$$

The linear correlations verified in each dimension, through the sectors, were described and analyzed regarding their importance, representativeness and used measurement unit. Later, the variables were organized according to the dimensions: economic, social, environmental and political, which built the energy sustainability indicators, and from each sector of activity, which made up the energy sustainability indices. In calculating the indicators, we proceeded from a weighted average composed of the result of the calculation of the composite variables. In calculating the composite variables, the calculation adopted two variables: the first referring to development, and the other referring to the energy environment.

Table 1 shows the construction structure of the index and the electricity sustainability indicators for the agricultural sector in Pará. 
Table 1: Structure of construction of electricity sustainability indicators in the agricultural sector of Pará, Brazil.

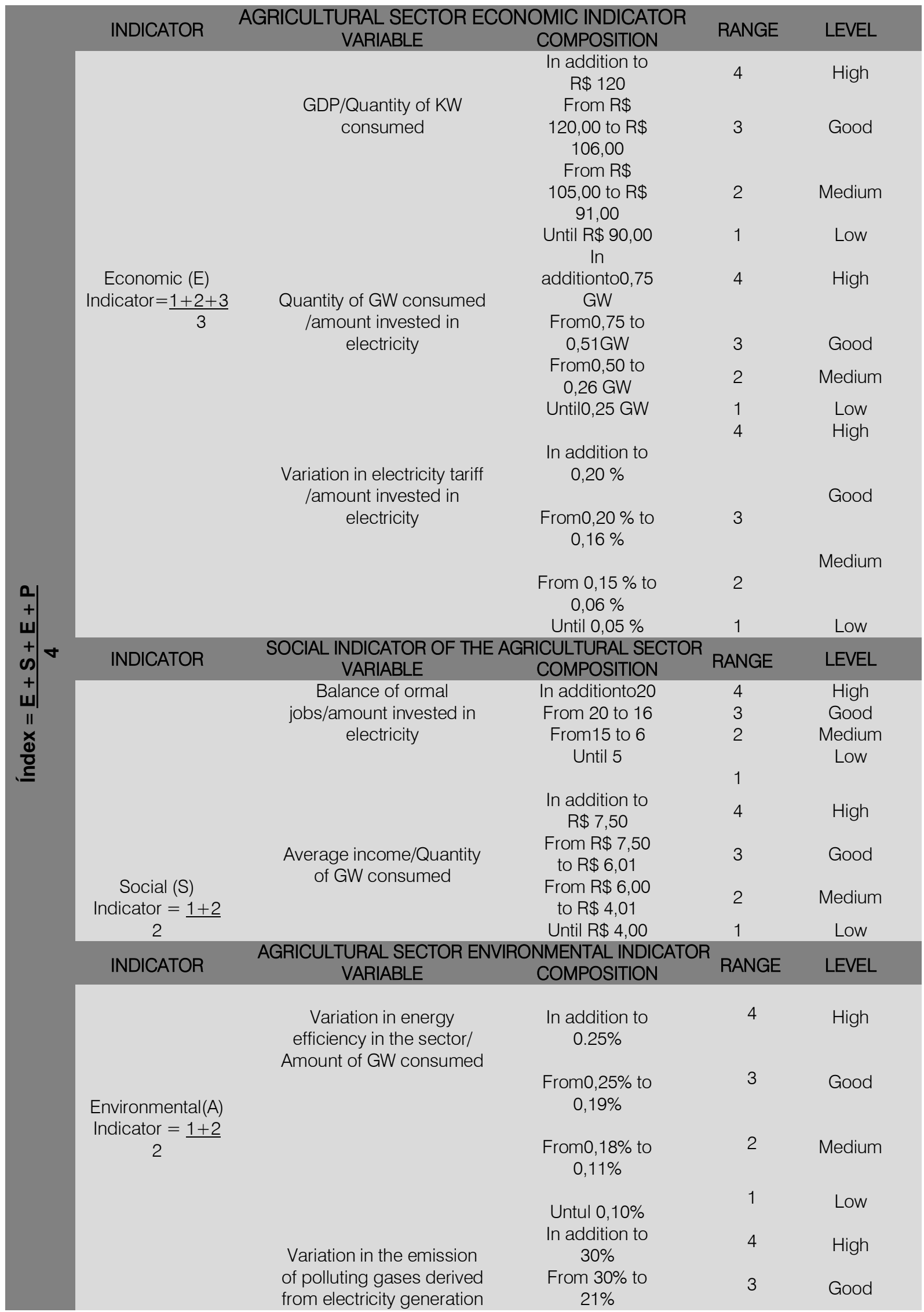




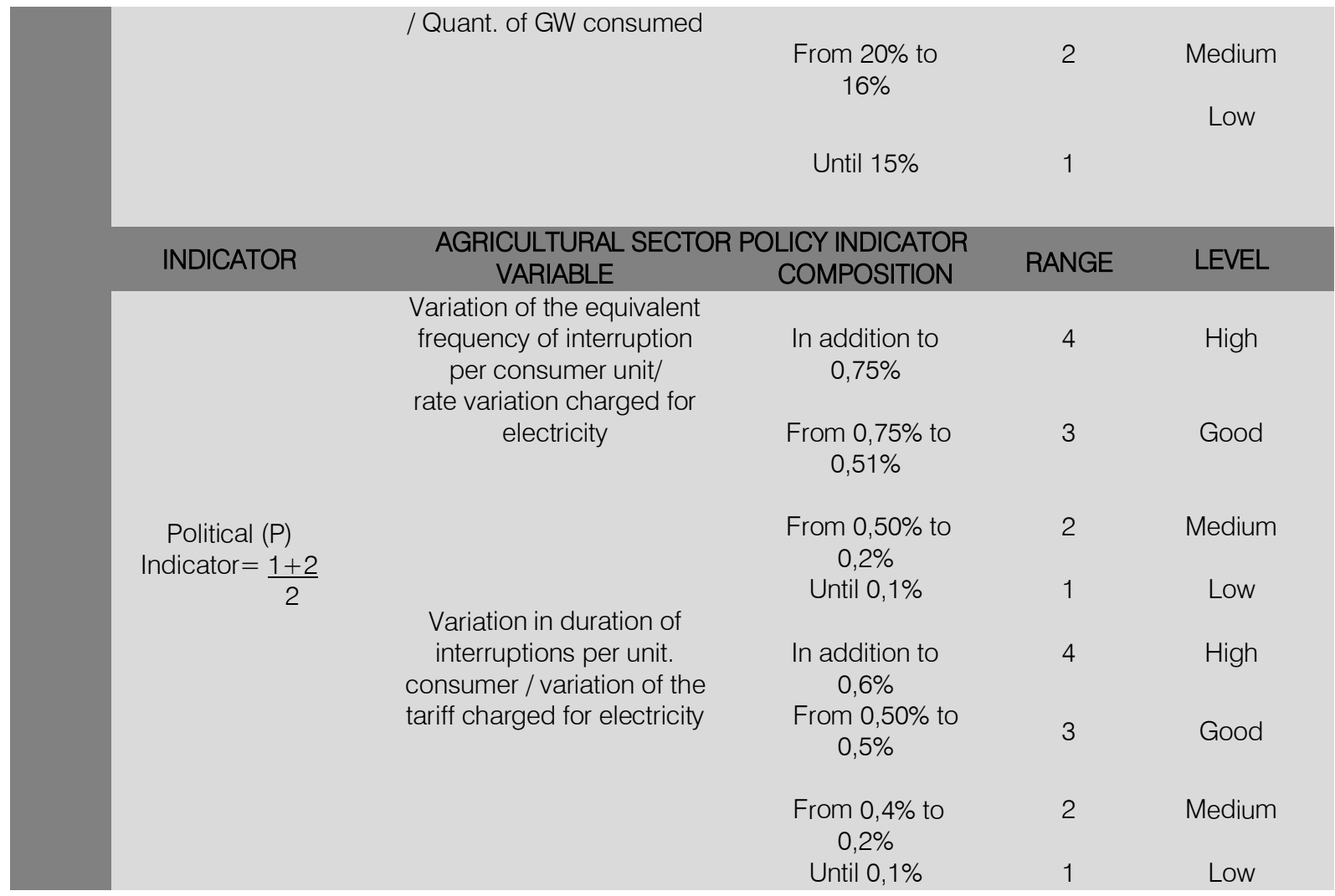

Source: Prepared by the authors (2021).

Table 2 shows the construction structure of the electricity sustainability index and indicators for the industrial sector in Pará.

Table 2: Structure of construction of electricity sustainability indicators in the industrial sector of Pará, Brazil.

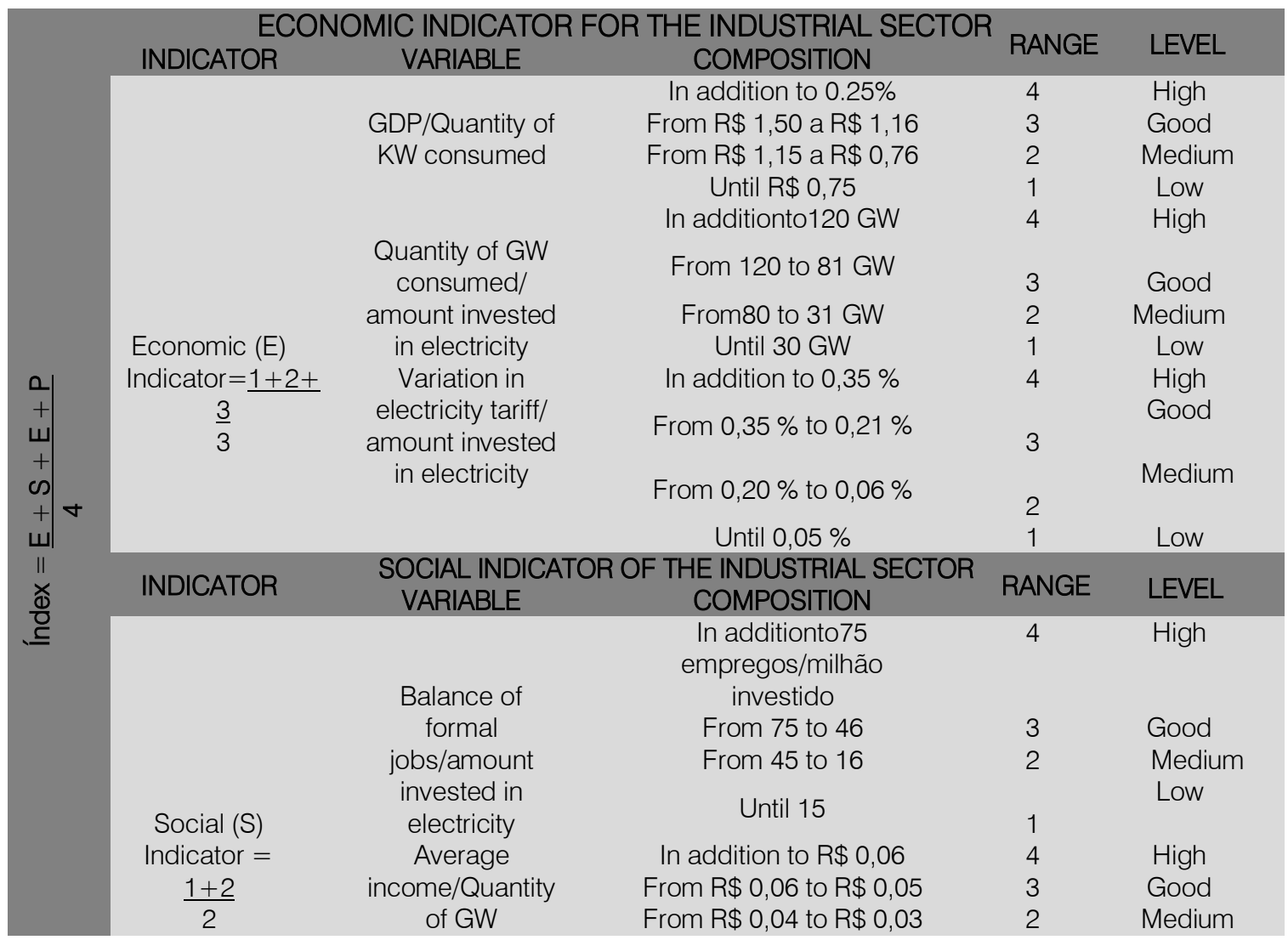




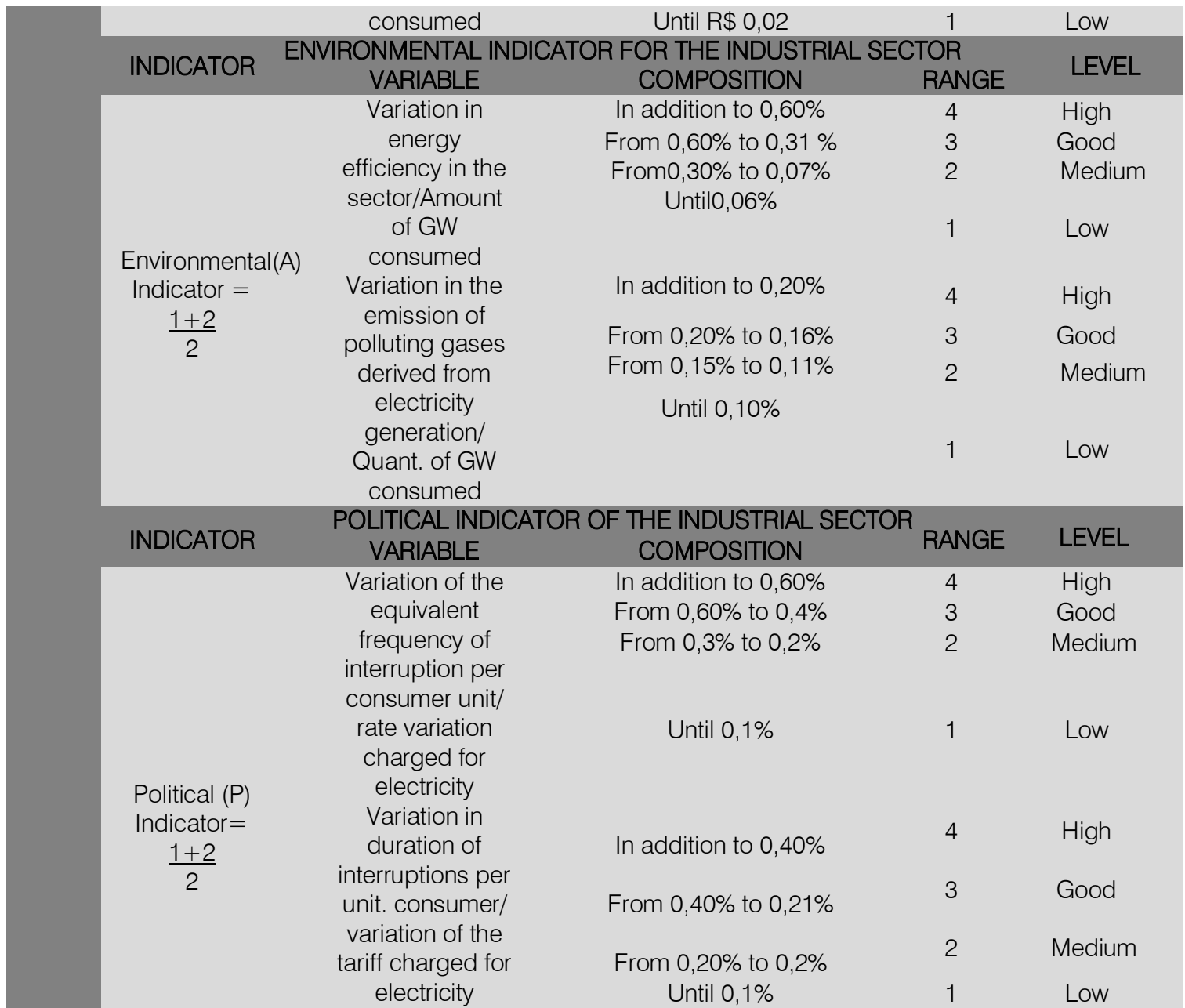

Source: Prepared by the authors (2021).

Table 3 shows the construction structure of the electricity sustainability index and indicators for the industrial sector in Pará.

Table 3: Structure of construction of electricity sustainability indicators in the commercial sector of Pará.

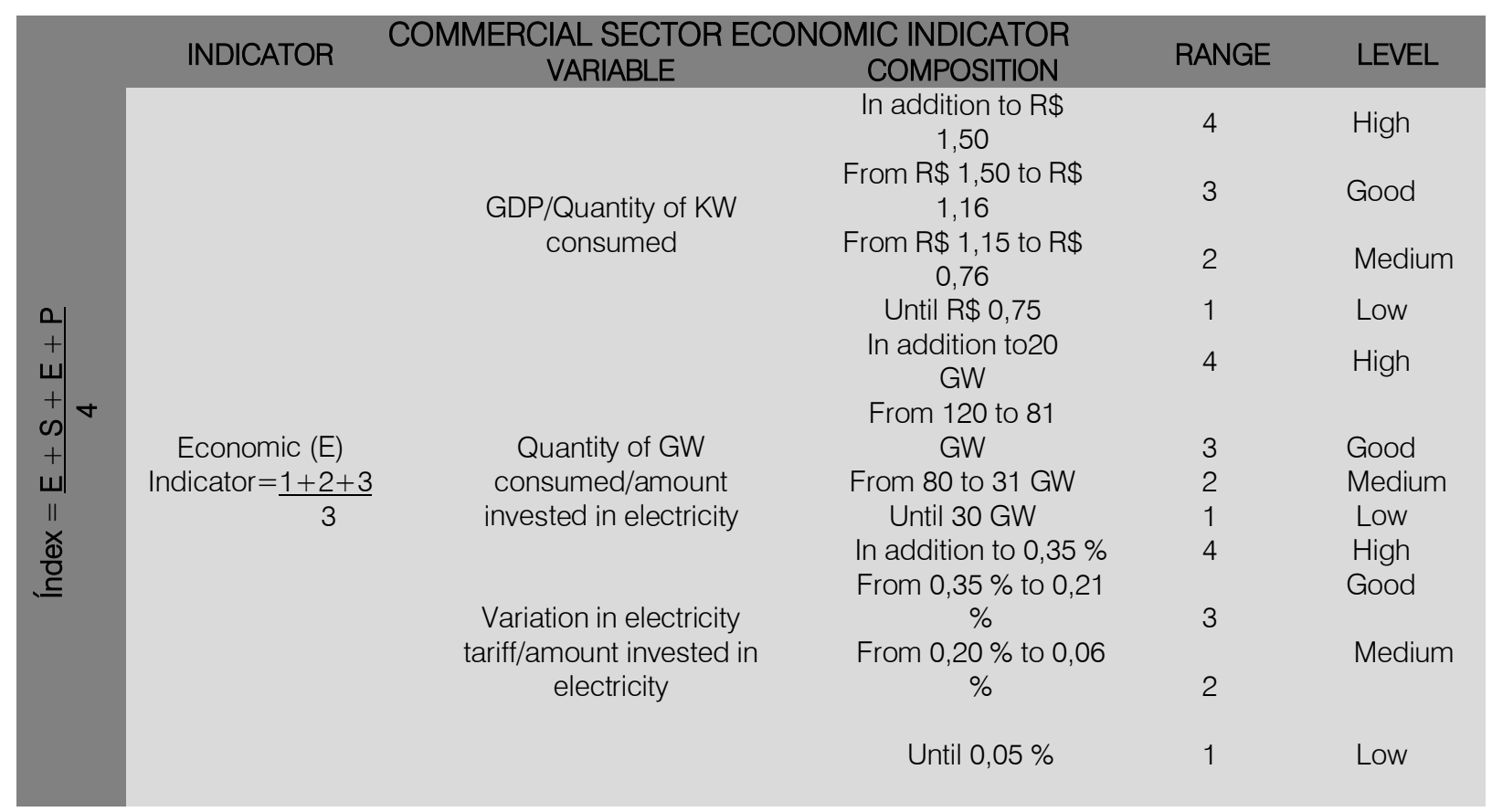




\begin{tabular}{|c|c|c|c|c|}
\hline INDICATOR & \multicolumn{2}{|c|}{ COMMERCIAL SECTOR SOCIAL INDICATOR } & RANGE & LEVEL \\
\hline \multirow{9}{*}{$\begin{array}{c}\text { Social (S) } \\
\text { Indicator }=\frac{1+2}{2}\end{array}$} & \multirow{4}{*}{$\begin{array}{c}\text { Balance of formal } \\
\text { jobs/amount invested in } \\
\text { electricity }\end{array}$} & In addition to 75 & 4 & \multirow{4}{*}{$\begin{array}{l}\text { High } \\
\text { Good } \\
\text { Medium } \\
\text { Low }\end{array}$} \\
\hline & & From 75 to 46 & 3 & \\
\hline & & From 45 to 16 & 2 & \\
\hline & & Until15 & & \\
\hline & & In addition to $\mathrm{R} \$ 0,06$ & 4 & High \\
\hline & Average & $\begin{array}{c}\text { From } \mathrm{R} \$ 0,06 \text { to } \mathrm{R} \$ \\
0,05\end{array}$ & 3 & Good \\
\hline & income/Quantity of GW & From $R \$ 0,04$ to $R \$$ & 0 & \\
\hline & consumed & 0,03 & 2 & Medium \\
\hline & & Until $R \$ 0,02$ & 1 & Low \\
\hline INDICATOR & $\begin{array}{c}\text { COMMERCIAL SECTOR EI } \\
\text { VARIABLEL }\end{array}$ & $\begin{array}{l}\text { NMENTAL INDICATOR } \\
\text { COMPOSITION }\end{array}$ & RANGE & LEVEL \\
\hline \multirow{8}{*}{$\begin{array}{l}\text { Environmental }(\mathrm{A}) \\
\text { Indicator }=\frac{1+2}{2}\end{array}$} & \multirow{8}{*}{$\begin{array}{c}\text { Variation in energy } \\
\text { efficiency in the sector / } \\
\text { Amount of GW } \\
\text { consumed } \\
\text { Variation in the emission } \\
\text { of polluting gases } \\
\text { derived from electricity } \\
\text { generation / Quant. of } \\
\text { GW consumed }\end{array}$} & In addition to $0,60 \%$ & 4 & \multirow{4}{*}{$\begin{array}{l}\text { High } \\
\text { Good } \\
\text { Medium } \\
\text { Low }\end{array}$} \\
\hline & & From $0,60 \%$ to $0,31 \%$ & 3 & \\
\hline & & From $0,30 \%$ to $0,07 \%$ & 2 & \\
\hline & & Até $0,06 \%$ & 1 & \\
\hline & & In addition to $0,20 \%$ & 4 & High \\
\hline & & From $0,20 \%$ to $0,16 \%$ & 3 & Good \\
\hline & & From $0,15 \%$ to $0,11 \%$ & 2 & Medium \\
\hline & & Untul $0,10 \%$ & 1 & Low \\
\hline \multirow{2}{*}{ INDICATOR } & \multirow{2}{*}{\multicolumn{2}{|c|}{$\begin{array}{l}\text { COMMERCIAL SECTOR POLICY INDICATOR } \\
\text { VARIABLE } \\
\text { COMPOSITION }\end{array}$}} & & \\
\hline & & & RANGE & LEVEL \\
\hline \multirow{8}{*}{$\begin{array}{c}\text { Political }(P) \\
\text { Indicator }=\frac{1+2}{2}\end{array}$} & \multirow{8}{*}{$\begin{array}{l}\text { Variation of the } \\
\text { equivalent frequency of } \\
\text { interruption per } \\
\text { consumer unit/ } \\
\text { rate variation charged } \\
\text { for electricity } \\
\text { Variation in duration of } \\
\text { interruptions per unit. } \\
\text { consumer/variation of } \\
\text { the tariff charged for } \\
\text { electricity }\end{array}$} & In addition to $0,60 \%$ & 4 & High \\
\hline & & From $0,60 \%$ a $0,4 \% 3$ & 3 & Good \\
\hline & & From $0,3 \%$ to $0,2 \%$ & 2 & Medium \\
\hline & & Untiul0,1\% & 1 & Low \\
\hline & & In addition to $0,40 \%$ & 4 & High \\
\hline & & From $0,40 \%$ to $0,21 \%$ & 3 & Good \\
\hline & & From $0,20 \%$ to $0,2 \%$ & 2 & Medium \\
\hline & & Until0,1\% & 1 & Low \\
\hline
\end{tabular}

Source: Prepared by the authors (2021).

In the methodological strategy of this study, each sector of economic activity was assessed based on the components of the decision structure proposed
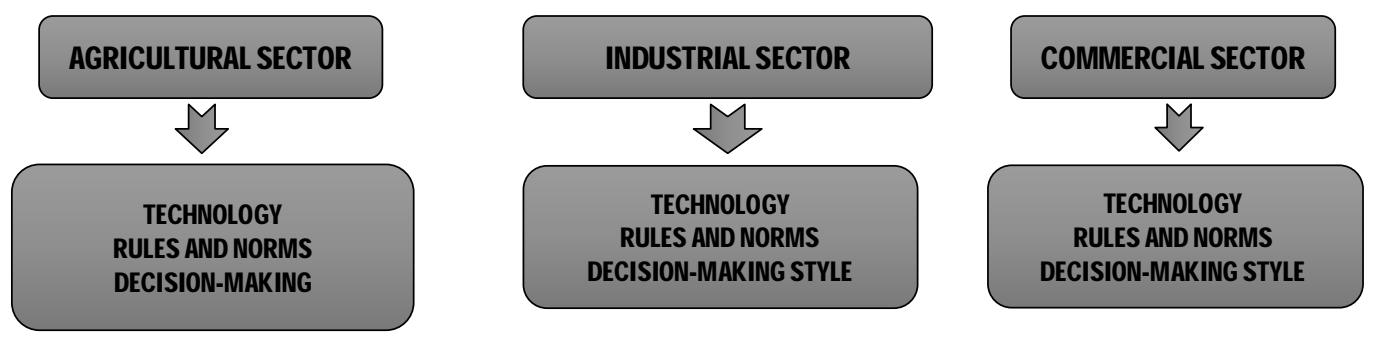

Source: Prepared by the authors (2021).

Figure 1: Structure of the decision-making process in public management. 
Next, the results and discussions relevant to the calculation of energy sustainability indicators and the provision of subsidies to the decision-making process in the electricity sector will be presented, Which considers the intricacies of technology, rules and

\section{Results And Discussions}

This section will be composed, firstly, by the presentation of the results of the sectorial indicators of electric energy sustainability and their analysis, in the scope of each economic activity sector. Then, a decision-orientation model will be presented, which considers the intricacies of technology, rules and standards, and decision-making style, fed by the results of the sector sustainability indicators measured for the State of Pará, between 2010 and 2019.

Below, in Tables 4 and 5, the results of the investigation on energy sustainability indicators in the agricultural sector of the State of Pará are presented.

Table 4: Score of ranges for calculating energy sustainability indicators in the agricultural sector in Pará (2010-2019).

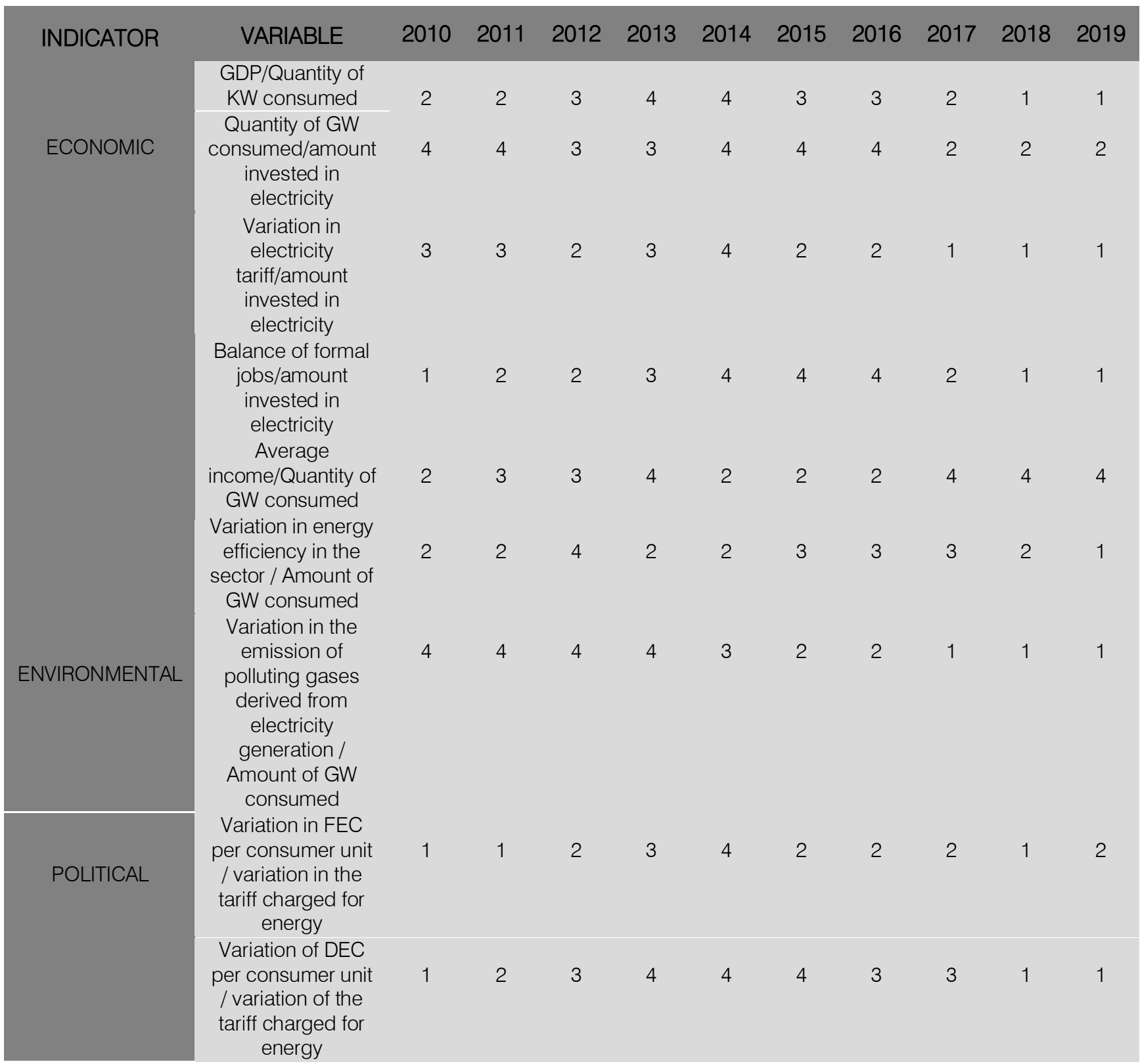

Source: Prepared by the authors (2021). Legend: 4= High Level; 3= Good Level; 2= Medium Level; $1=$ Low Level.

In the agricultural sector, the highlight was the social and environmental dimensions, with positive results, predominantly registering indicators with levels between Good and Medium. 
Table 5: Energy sustainability indicators in the agricultural sector (2010-2019).

$\begin{array}{ccccccccccc}\text { INDICADOR } & 2010 & 2011 & 2012 & 2013 & 2014 & 2015 & 2016 & 2017 & 2018 & 2019 \\ \text { Economic } & \text { Good } & \text { Good } & \text { Good } & \text { Good } & \text { High } & \text { Good } & \text { Good } & \text { Medium } & \text { Low } & \text { Low } \\ \text { Social } & \text { Medium } & \text { Medium } & \text { Medium } & \text { Good } & \text { Good } & \text { Good } & \text { Good } & \text { Medium } & \text { Medium } & \text { Medium } \\ \text { Environmental } & \text { Good } & \text { Good } & \text { High } & \text { Good } & \text { Medium } & \text { Medium } & \text { Medium } & \text { Medium } & \text { Medium } & \text { Low } \\ \text { Political } & \text { Low } & \text { Low } & \text { Medium } & \text { Good } & \text { High } & \text { Good } & \text { Medium } & \text { Medium } & \text { Low } & \text { Low }\end{array}$

Source: Prepared by the authors (2021).

In the agricultural sector, the highlight was the social and environmental dimensions, with positive results, predominantly registering indicators with levels between Good and Medium. In the years 2018 and 2019, the panorama changed as there were records of Low level indicators in the economic, environmental and political dimensions in the sector. The environmental dimension is a concern regarding sustainability and the possibility of measurement in this study is in line with the reality portrayed that ways to measure sustainable development are being structured and tested in various

Below, in Tables 6 and 7, the results of the investigation on energy sustainability indicators in the industrial sector of the State of Pará are presented.

Table 6: Score of ranges for calculating energy sustainability indicators of the industrial sector in Pará, Brazil parts of the world (Lira, 2008). The political dimension was the one with the most weaknesses in the period studied. These weaknesses reveal the inadequate energy supply of a large portion of Pará society, which influences public management with lesser decisionmaking power. Thus, part of society ends up benefiting at the expense of others, demonstrating the influence of different ideologies of groups that interfere with more decision-making power in public management (Schultz, 2016).

\section{(2010-2019).}

\begin{tabular}{|c|c|c|c|c|c|c|c|c|c|c|}
\hline VARIABLE & 2010 & 2011 & 2012 & 2013 & 2014 & 2015 & 2016 & 2017 & 2018 & 2019 \\
\hline $\begin{array}{l}\text { GDP/Quantity of } \\
\text { KW consumed } \\
\text { Quantity of GW }\end{array}$ & 2 & 2 & 2 & 3 & 3 & 2 & 2 & 4 & 3 & 3 \\
\hline $\begin{array}{cc} & \text { consumed/ } \\
\text { amount invested } \\
\text { in electricity } \\
\bar{\Sigma} \\
\bar{\delta} & \text { Variation in }\end{array}$ & 4 & 4 & 3 & 3 & 3 & 2 & 2 & 1 & 1 & 1 \\
\hline $\begin{array}{l}\text { electricity } \\
\text { tariff/amount } \\
\text { invested in } \\
\text { electricity from } \\
\text { Balance of }\end{array}$ & 3 & 3 & 2 & 3 & 3 & 4 & 3 & 1 & 1 & 1 \\
\hline $\begin{array}{l}\text { formal } \\
\text { jobs/amount } \\
\text { invested in } \\
\text { electricity }\end{array}$ & 4 & 4 & 2 & 2 & 1 & 4 & 2 & 2 & 2 & 1 \\
\hline $\begin{array}{c}\text { Average } \\
\text { \& } \\
\text { income/Quantity } \\
\text { of GW } \\
\text { consumed } \\
\text { Variation in }\end{array}$ & 1 & 2 & 2 & 2 & 1 & 1 & 3 & 3 & 4 & 2 \\
\hline 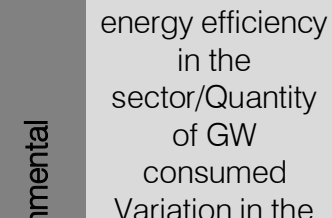 & 2 & 3 & 1 & 1 & 4 & 1 & 3 & 1 & 4 & 2 \\
\hline $\begin{array}{cc}\text { Darlation In the } \\
\text { emission of } \\
\text { polluting gases } \\
\text { derived from } \\
\text { electricity } \\
\text { generation / }\end{array}$ & 2 & 3 & 4 & 2 & 1 & 1 & 2 & 2 & 2 & 2 \\
\hline
\end{tabular}




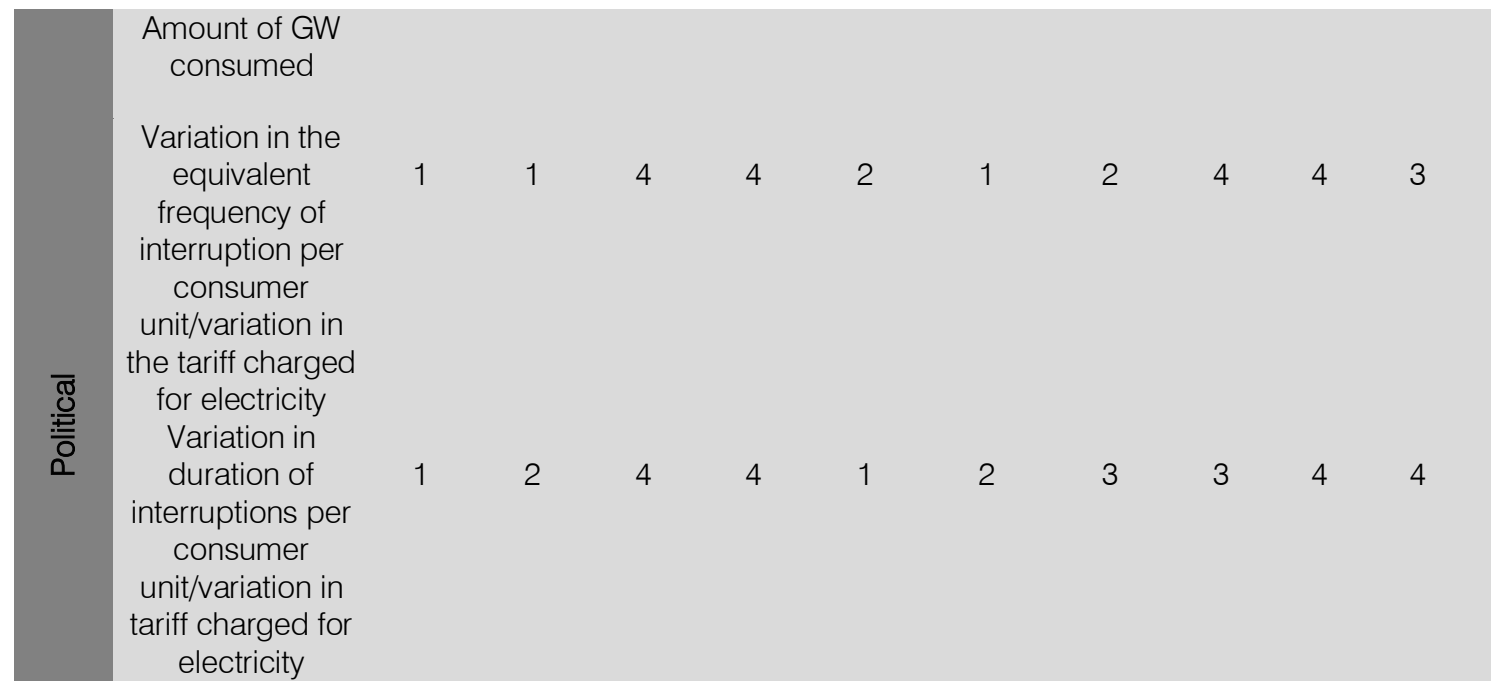

Source: Prepared by the authors (2021). Legend: 4= High Level; 3= Good Level; 2= Medium Level; $1=$ Low Level.

In the industrial sector, the positive highlight the one with the most weaknesses in the sector during was the economic dimension, also with a predominance the period analyzed. of Medium and Good levels. The political dimension was

Table 7: Energy sustainability indicators in the industrial sector (2010-2019).

$\begin{array}{lllllllllll}\text { INDICATOR } & 2010 & 2011 & 2012 & 2013 & 2014 & 2015 & 2016 & 2017 & 2018 & 2019 \\ \text { Economic } & \text { Good } & \text { Good } & \text { Good } & \text { Good } & \text { Good } & \text { Good } & \text { Good } & \text { Medium } & \text { Medium } & \text { Medium } \\ \text { Social } & \text { Medium } & \text { Good } & \text { Medium } & \text { Medium } & \text { Low } & \text { Medium } & \text { Medium } & \text { Medium } & \text { Good } & \text { Low } \\ \text { Environmental } & \text { Medium } & \text { Good } & \text { Medium } & \text { Low } & \text { Medium } & \text { Low } & \text { Medium } & \text { Low } & \text { Good } & \text { Medium } \\ \text { Polítical } & \text { Low } & \text { Low } & \text { High } & \text { High } & \text { Low } & \text { Low } & \text { Medium } & \text { Good } & \text { High } & \text { Good }\end{array}$

Source: Prepared by the authors (2021).

The indicators measured reveal an important responsibility to the framework of environmental unsustainability insofar as they point to a profile endowed with large proportions of consumption, added to the relatively low energy yields verified in the analyzed period. The encouragement of mechanisms that strategically redirect the industrial profile of Pará to the condition of contributing to income deconcentration could be operated by increasing the state tax burden for exports of heavy industry products from Pará. The change in the industrial profile would occur through the absence of tax incentives for the segments identified by the study: ferroalloy, aluminum, steel, pulp and paper and chemical products, and the provision of these incentives to the food and beverage, textile and cement industries. The industrial profile of Pará signals the absence of priority aspects to the development process, particularly in relation to the variables that affect the sustainability of the sector, which is in line with the considerations of several authors on the association between energy use and development (Camargo, Ugaya, Agudelo, 2004; Moldan, Janousková, Hák, 2012; Cornescu, Adam, 2014; Silva et al., 2018).

Below, in Tables 8 and 9, the results of the investigation on energy sustainability indicators in the commercial sector of the State of Pará are presented.

Table 8: Score of ranges for calculating energy sustainability indicators of the commercial sector in Pará, Brazil (2010-2019).

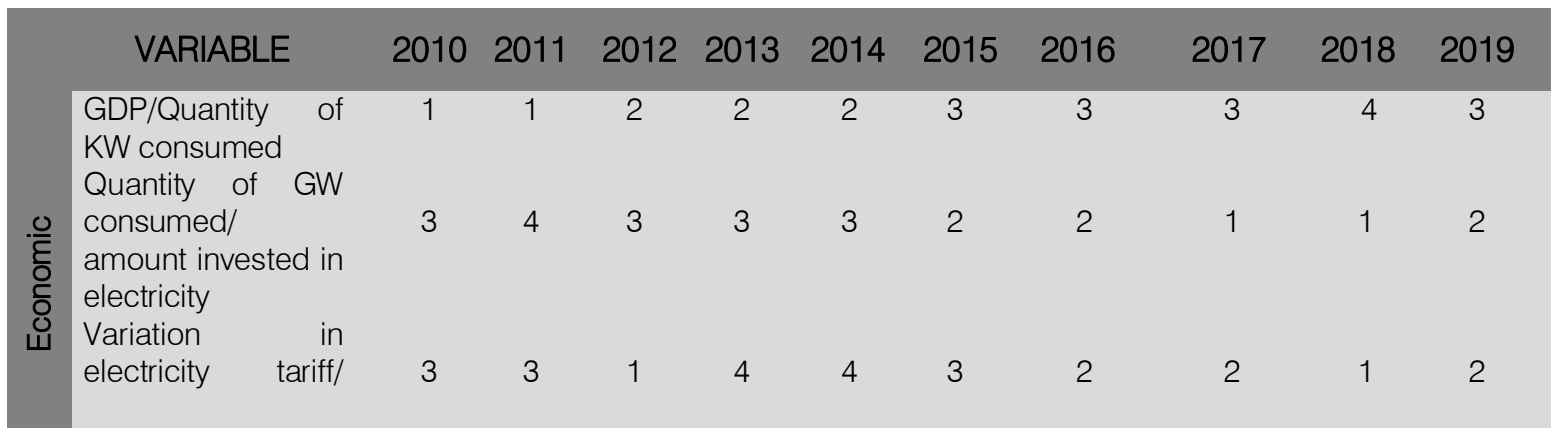


amount invested in

electricity

Balance of formal

jobs/ amount

invested in

electricity

Average income/

Quantity of GW

consumed

Variation in energy

efficiency in the

sector/ Quantity of

GW consumed

क्ष

Variation in the

emission of

polluting gases

derived rom

electricity

generation/

Amount of GW

consumed

Resultados de

tradução

Variation in the

equivalent

frequency of

interruption per

consumer

unit/variation in the

tariff charged for

electricity

Variation

in

duration of

interruptions per

consumer unit/

variation in tariff

charged for

electricity

Source: Prepared by the authors (2021). Legend: 4= High Level; 3= Good Level; 2= Medium Level; $1=$ Low Level.

In the commercial sector, positive attention was given to the economic and social dimensions, registering indicators of Medium and Good levels. The

Table 9: Energy sustainability indicators in the commercial sector (2010-2019).

$\begin{array}{ccccccccccc}\text { INDICADOR } & 2010 & 2011 & 2012 & 2013 & 2014 & 2015 & 2016 & 2017 & 2018 & 2019 \\ \text { Economic } & \text { Good } & \text { Medium } & \text { Medium } & \text { Good } & \text { Good } & \text { Good } & \text { Medium } & \text { Medium } & \text { Medium } & \text { Medium } \\ \text { Social } & \text { Medium } & \text { Medium } & \text { Medium } & \text { Medium } & \text { Medium } & \text { Good } & \text { Medium } & \text { Medium } & \text { Good } & \text { Good } \\ \text { Environmental } & \text { Medium } & \text { Good } & \text { Medium } & \text { High } & \text { Medium } & \text { Medium } & \text { Medium } & \text { Medium } & \text { Medium } & \text { Low } \\ \text { Político } & \text { Low } & \text { Low } & \text { Medium } & \text { High } & \text { Low } & \text { Medium } & \text { Medium } & \text { Medium } & \text { Low } & \text { Low }\end{array}$

Source: Prepared by the authors (2021).

The decentralization of energy planning, through the creation of the State Energy Policy Council (CEPE), would ensure that the guidelines and strategies designed for the electricity sector in Pará were conducted not only in accordance with the federal government's global interests, but also in a manner to ensure compliance with the demands of society in the state supplying this electricity. What meets the concerns of managers to achieve qualitative results in public political dimension, like other sectors, was the one that presented the most difficulties. management with regard to financial resources applied in the territory (Mafra; Silva, 2004).

In Table 10, below, a structure for decisionmaking guidance based on the results of the sectorial indicators of sustainability of electricity in Pará, measured in the period from 2010 to 2019, is presented. Suggestions for alternative actions within each of the sectors of economic activity and that considers the economic, social, environmental and political 
dimensions, have the purpose of making corrections in the efficiency of the relations between electricity and development, in order to contribute to the increase in the level of these indicators.

Table 10: Framework for decision-making guidance based on the results of the sectorial indicators of sustainability of electricity in Pará.

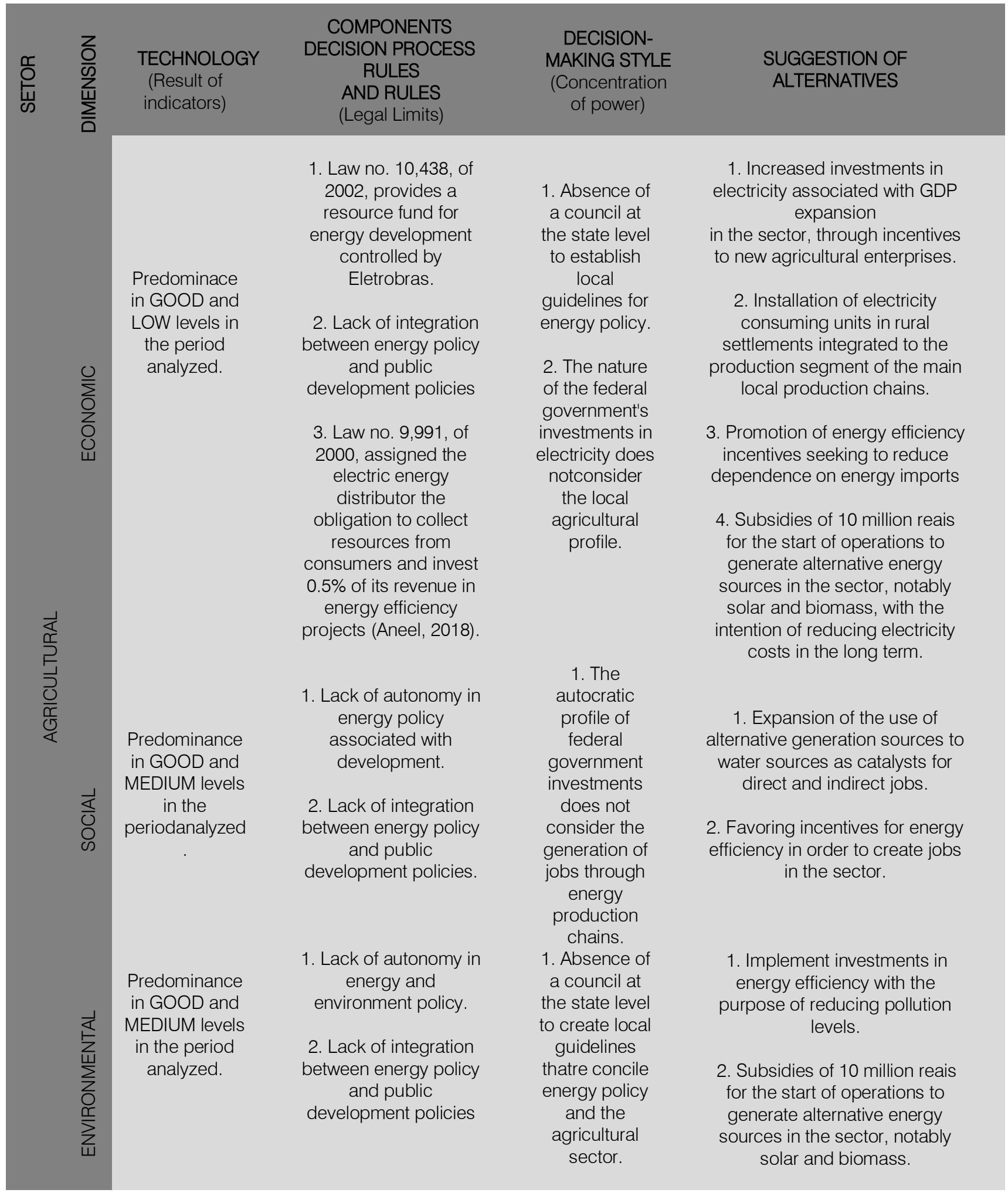


Predominance in MEDIUM and LOW

levels in the period analyzed.

Predominance at GOOD level. MEDIUM level in recent years of the period analyzed.

Predominance at MEDIUM level in the period analyzed.

Predominance in MEDIUM and LOW levels in the period analyzed.

\section{Absence of state autonomy in energy policy.}

2. Lack of integration between energy policy and effective citizen participation.

1. Law no. 10,438 , of 2002, provides a resource fund for energy development controlled by Eletrobras.

2. Lack of integration between energy policy and public development policies

3. Law No. 9,991, of 2000, assigned the energy distributor the obligation to collect resources from users and invest $0.5 \%$ of its revenue in efficiency projects (Aneel, 2018).

\section{Lack of autonomy in energy policy associated with development.}

2. Lack of integration between energy policy and public development policies

\section{Lack of autonomy in} energy and environment policy.

2. Lack of integration between energy policy and public development policies
1. Lack of a state council to create mechanisms for associating the quality of electricity services and the tariff charged.

1. Absence of a council at the state level to establishan association between energy policy and the local industrial profile.

1. The autocratic profile of federal government investments does not consider the generation of jobs through energy production chains.

2. Absence of a state council to establish local guidelines thatre concile energy policy and the sector.

1. Absence of a council at the state level to establish local guidelines for the

containment of environmental impacts caused by the energy input.

\section{Creation of the State Energy Policy Council (CEPE).}

2. Regulation, by Aneel, of tariffs based on the quality of supply.

3. Quality could be verified by the number of interruptions in the supply of electricity and the duration of these interruptions.

1. I encourage mechanisms that direct the industrial profile of

Pará to the condition of contributing to the deconcentration of income, that is, promoting changes in the composition of exports in the heavy industry.

2. Promotion of energy efficiency incentives seeking to reduce dependence on energy imports

1. Expansion of the use of alternative generation sources to water sources as catalysts for direct and indirect jobs.

2. Reduced working hours in energy-intensive industries to generate new jobs.

3. Favoring incentives for energy efficiency in order to create jobs in the sector.

1. Incorporation of compensatory devices for environmental costs in the sector based on accounting mechanisms for price formation.

2. Implement investments in energy efficiency with the purpose of reducing pollution levels.

3. Subsidies of 10 million reais for the start of operations to generate alternative energy sources in the sector, notably solar and biomass. 
Predominance in levels ranging from $\mathrm{HIGH}$ to

LOW in the period analyzed.

Predominance in GOOD and MEDIUM levels in the period analyzed.

Predominance in GOOD and MEDIUM levels in the period analyzed.

Predominance at MEDIUM

level in the period analyzed.
1. Lack of integration between energy policy and effective citizen participation.

\section{Absence of state autonomy in energy policy.}

1. Law no. 10,438 , of 2002, provides a resource fund for energy development controlled by Eletrobras.

2. Lack of integration between energy policy and public development policies

3. Law No. 9,991, of 2000 , assigned the electricity distributor the obligation to collect funds from consumers and invest $0.5 \%$ of its revenue in energy efficiency projects (Aneel, 2018)

1. Lack of autonomy in energy policy associated with development.

2. Lack of integration between energy policy and public development policies

1. Lack of autonomy in energy and environment policy.

2. Lack of integration between energy policy and public development policies
1. Lack of a

state council to establish

mechanisms

for associating

the quality of electricity services and the tariff

charged in the sector.

\section{Absence of} a council at the state level to establish an association between energy policy and the profile of local commerce.

1. Absence of a council at the state level to establish local guidelines thatre concile energy policy and the sector.

1. Absence of a state council to establish local guidelines for the

containment of environmental impacts

caused by the energy input.

\section{Creation of the State Energy Policy Council (CEPE).}

2. Regulation, by Aneel, of tariffs based on the quality of supply, where the referred quality can be verified through the number of interruptions in the supply of electricity and the duration of these interruptions.

1. Increased investments in electricity associated with GDP expansion

in the sector, in order to promote programs for the use of alternative energy to offset existing electricity bills.

2. Promotion of energy efficiency incentives seeking to reduce dependence on energy imports

1. Linking of special reduced tariff bands for companies in the sector with a large number of jobs.

2. Favoring incentives for energy efficiency in order to create jobs in the sector

1. Subsidies of 10 million reais for the start of operations to generate alternative energy sources in the sector, notably solar and biomass.

2. Implement investments in energy efficiency with the purpose of reducing pollution levels. 


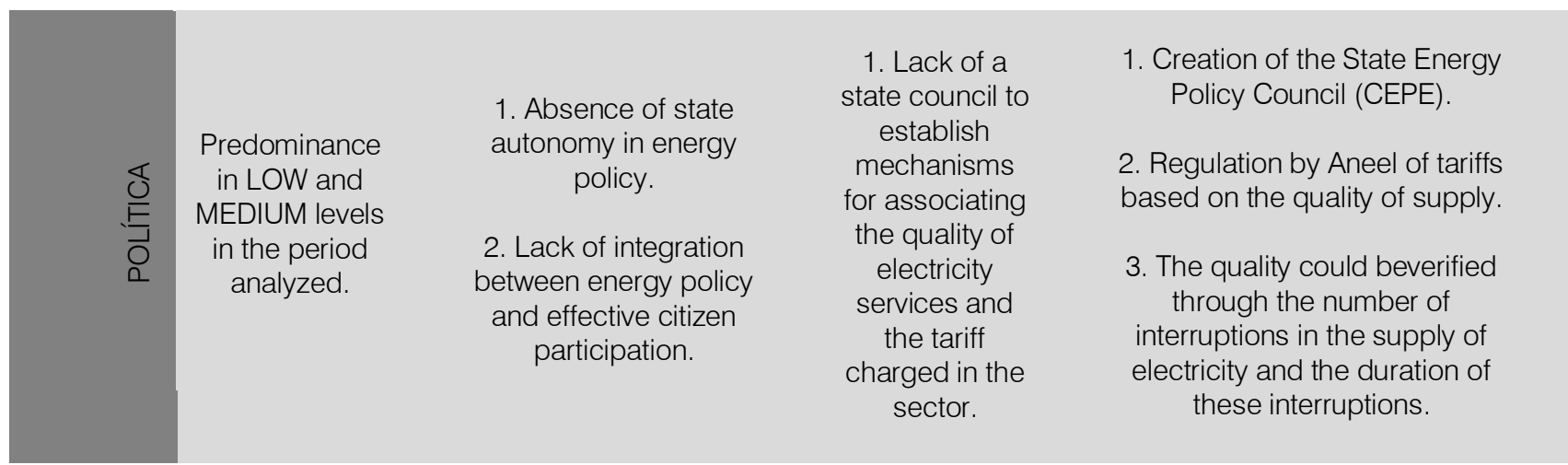

Source: Prepared by the authors (2021).

The actions based on the results of the sectorial indicators of electricity sustainability for the State of Pará were divided into three stages: short, medium and long term. In the short term, the study recommends: a) decentralization of energy planning through the creation of the State Energy Policy Council (CEPE); b) establishment of a local integrated strategic planning model that uses as an instrument the methodological framework for the construction of energy sustainability indicators and indices, proposed in this article; c) maintain the flow of investments in electricity to maintain Gross Domestic Product - GDP expansion in all sectors; and d) regulation of tariffs based on the quality of supply.

In the medium term, the following are indicated: a) the implementation of social sustainability programs with the energy environment of the agricultural sector, including production chains, and of the industrial sector, reducing the workload in energy-intensive industries; b) incorporation of compensatory devices for environmental costs in the industrial sectors.

In the long term, it is recommended: a) the encouragement of mechanisms that strategically direct the industrial profile of Pará, promoting changes in the composition of heavy industry exports (from the increase in the state tax burden for exports of heavy industry products from Pará) and changing the industrial profile, in order to withdraw tax incentives to the segments identified by the study: ferroalloy, aluminum, steel, pulp and paper and chemical products, and the provision of these incentives to the food and beverage, textile and cement industries, sectors these indicated by the results of the analyzes carried out); and b) increase in the energy efficiency of electricity through credit lines to agricultural enterprises that intend to exchange equipment with high electricity consumption.

\section{Final Considerations}

The study elaborated an original decision planning model based on sectorial indicators of electricity sustainability in the state of Pará, capable of contributing to the planning of public actions for sustainable development in Pará, according to the results of these indicators measured by sector of economic activity.

The indicators calculated in this investigation revealed a particular reality in each sector of economic activity in the State of Pará. In the agricultural sector, the highlight was the social and environmental dimensions, with positive results, registering levels between Good and Medium. In the industrial sector, the positive highlight was the economic dimension, also with a predominance of Medium and Good levels. In the commercial sector, the positive highlight was the economic and social dimensions, recording, in the same way, Medium and Good levels. The political dimension was the one that showed the most weaknesses in the period surveyed, in all sectors of economic activity in Pará.

The study also presented a decision-making model that suggested actions linked to increasing energy autonomy in Pará, redirecting the industrial profile, including compensatory devices for environmental costs, directing investments to increase GDP in the reality of each sector of economic activity, among other recommendations. The article contributed through: an originality of analysis that reveals the strategic usefulness of knowing the energy specificities of each economic sector and how electricity reflects on the productive processes of each sector; a reinterpretation of the Brazilian energy plan from a decision analysis dynamic that considers the regional specificities for the strategic use of the energy input; and the possibility of using a decision-making model in the electricity sector applicable to any state in Brazil.

New investigations can follow the methodological dynamics presented in this study and the residential sector would be the one that would most add to the deepening of the understanding of this theme. The residential sector comprises a relevant environment for examining the reality of meeting basic energy needs, as it identifies the socioeconomic profile of households in a given population and their conditions of access to energy input. 


\section{References Références Referencias}

1. Agência Nacional de Energia Elétrica. (2018). Nota Técnica no 0158/2018-SPE-SRM/ANEEL, de 05/06/2018. http://www. aneel gov.br/relatorios-deconsumo-e-receita. Acesso em: 17/09/2020.

2. Agência Nacional de Energia Elétrica. (2020). Relatórios de consumo e receita da distribuição. http://www. aneel gov.br/relatorios-de-consumo-ereceita. Acesso em: 17/09/2020.

3. Agência Nacional de Energia Elétrica. (1999). Proposta de indicadores de sustentabilidade energética da ANEEL. Brasília.

4. Amaral, A. B. A. (2017). O impacto da insuficiência no fornecimento de energia elétrica nas empresas brasileiras do setor de telecomunicações. (Dissertação de Mestrado). Departamento de Engenharia da Produção. USP, São Paulo.

5. Aragón, L. E. (1997). Desenvolvimento sustentável e cooperação internacional. In: XIMENES, Tereza (Org.) Perspectivas do desenvolvimento sustentável. Belém: NAEA/UFPA.

6. Banco Central do Brasil. (2018). Economia paraense: estrutura produtiva e desempenho recente. Boletim regional. Brasília, v. 12, n. 1, jan.

7. Bermann. C. (2003). Energia no Brasil: para quê? Para quem? Crise e alternativas para um país sustentável. São Paulo: Livraria da Física.

8. Binder, C. R.; Voet, E. Van Der; Rosselot, K. S. (2009). Implementing the results of material flow analysis. Journal of industrial ecology, v. 13, n. 5, p. 643-649.

9. Borges, F. Q. \& Zouain, D. M. (2010). A matriz elétrica no estado do Pará e seu posicionamento na promoção do desenvolvimento sustentável. IPEA. Planejamento e Políticas Públicas, 2(35), 187-221.

10. Borges, F. Q. (2012). Administração pública do setor elétrico: indicadores de sustentabilidade no ambiente residencial do estado do Pará (200110). Rev. Adm. Pública [online]. vol.46, n.3, pp. 737-751.

11. Borges, F. Q. (2015). Sustentabilidade institucional no setor elétrico brasileiro. Revista Pretexto. vol. 16, $\mathrm{n}^{\circ} .1$ - janeiro/março.

12. Camargo, A. S. G.; Ugaya, C. M. L.; Agudelo, L. P. P. (2004). Proposta de definição de indicadores de sustentabilidade para geração de energia elétrica. Revista Educação e Tecnologia. Rio de Janeiro: CEFET/PR/MG/RJ.

13. Campos, A. F.; Scarpati, C. de B. L.; Santos, L. T. dos; Pagel, U., R. \& Souza, V. A. de. (2017). Um panorama sobre a energia geotérmica no Brasil e no Mundo: Aspectos ambientais e econômicos. Revista Espacios. Vol. 38. $\mathrm{n}^{\circ} .1$

14. Chen, P. Y.; Popovic, P. M. (2002). Correlation. London: Sage.
15. Collaco, F. M. A.; Dias, L. P.; Simoes, S. G.; Pukset, T.; Seixas, J.; Bermann, C. (2019). What if megacities started to do Urban Energy Planning? The case study of São Paulo city and its implication for the national energy policy. Renewable Energy, v. 138, p. 416-433.

16. Cornescu, V.; Adam, R. (2014). Considerations regarding the role of indicators used in the analysis and assessment of sustainable development in the E.U. Procedia Economics and Finance, v. 8, p. 10-16.

17. Creti, A.; Nguyen, D. K.; Kilian, L. (2018). Special Issue Energy Challenges in an Uncertain World Editorial", The Energy Journal, Vol. 39, S/I.

18. Dagnino, R.; Cavalcanti, P. A.; Costa, G. (2016). Gestão estratégica pública. São Paulo: Fundação Perseu Abramo.

19. Fenzl, N. (1997). Estudo de parâmetros capazes de dimensionar a sustentabilidade de um processo de desenvolvimento. In: XIMENES, Tereza (Org.) Perspectivas do desenvolvimento sustentável. Belém: NAEA/UFPA.

20. Fischer-Kowalski M. et al. (1997). Gesellschaftlicher stoffwechsel und kolonisierung von natur. Amsterdam: Verlag Fakultas.

21. Helio International. (2005). Guidelines for observe: reporters. http://www.helio-international.org. Acesso em: 20/09/2020.

22. Instituto Brasileiro de Geografia e Estatística. (2020). Estimativas populacionais 2020. Rio de Janeiro: IBGE.

23. International Energy Agency. (2012). Key World Statistics. [s/l]: [s/e].

24. Kaltenegger, C. H. (1995). Der Reformproze in der VR China: aktueller stand der wirtschaftsreformen und aussichten. CA Quarterly I. [s/l]: [s/e].

25. Lira, W. S. (2008). Sistema de Gestão do Conhecimento para Indicadores de Sustentabilidade - SIGECIS: Proposta de uma metodologia Campina Grande- PB. (Tese de Doutorado). Universidade Federal de Campina Grande. Programa de Pós-Graduação em Recursos Naturais.

26. Mafra, F.; Silva, J. A. (2012) Planejamento e gestão do território. Porto: Sociedade portuguesa de inovação.

27. Moldan, Bedrich; Janousková, Svatava; Hák, Tomáš. (2004). How to understand and measure environmental sustainability: indicators and targets. Ecological Indicators, v. 17, p. 4-13.

28. Narayan, S.; Doytch, N. (2017). An investigation of renewable and non-renewable energy consumption and economic growth nexus using industrial and residential energy consumption. Energy Economics, [s. I.], v. 68, p. 160-176. <http://www.sciencedirect. 
com/science/article/pii/S0140988317303080 > .Aces so em: 18/9/2020.

29. Organização das Nações Unidas. (1995). Report of the secretary general commission on sustainable development: Work program on indicators of sustainable development. New York: UN/E/CN.

30. Pacheco; G. B.; Mattos, A. S. (2014). Processo decisório no setor público: um estudo de caso na Caixa Econômica Federal e na Universidade Federal de Santa Catarina. In: Anais do XIV Colóquio Internacional de Gestão Universitária - CIGU Florianópolis.

31. Pereira, J. M. (2018). Administração Pública: foco nas instituições e ações governamentais. São Paulo: Atlas.

32. Pires, J. C. L.; Goldstein, A. (2001). Agências reguladoras brasileiras: avaliação e desafios. Revista BNDES, n. 16, p. 3-42, dez.

33. Prado, A. L. (2015). Desenvolvimento Urbano Sustentável: de paradigma ao mito. Ocolum Ensaios, Capinas, n.12, v.1, p. 83-97, jan./jun.

34. Robbins, S. P. (2015). Decida e conquiste: o guia definitivo para tomada de decisão. São Paulo: Saraiva.

35. Reis, L. B.; Fadigas, E. A. F. A.; Carvalho, C. E.; (2012). Energia, recursos naturais e a prática do desenvolvimento sustentável. Coleção Ambiental. Barueri, SP: Manole.

36. Sachs, I. (2009). Caminhos para o desenvo/vimento sustentável. Rio de Janeiro: Garamond.

37. Saidi, K.; Rahman, M. M. \& Amamri, M. (2017). The causal nexus between economic growth and energy consumption: New evidence from global panel of 53 countries. Sustainable Cities and Society, [s. I.], v. 33, p. 45-56.

38. Schultz, G. (2016). Introdução à gestão de organizações. Porto Alegre: books.google.com.

39. Silva, J. F. B. A.; Rebouças, S. M. D. P.; Abreu, M. C. S. de; Ribeiro, M. da C. R. (2018). Construção de um índice de desenvolvimento sustentável e análise espacial das desigualdades nos municípios cearenses. Rev. Adm. Pública [online]. Rio de Janeiro 52(1):149-168, jan.-fev.

40. Silva, R. M. P. (2013). Análise do processo decisório na administração pública e sistemas de apoio à tomada de decisão: contradições e paradoxos na realidade organizacional pelo não uso de ferramentas disponíveis. (Tese de Doutorado). Universidade Federal do Rio Grande do Sul, Escola de Administração, Programa de Pós-Graduação em Administração, Porto Alegre.

41. Smil, V. (1993). China's Environmental Crisis: an inquiry into the limits of national development. New York: East Gate.

42. Stahel, A. W. (1995). Capitalismo e entropia: os aspectos ideológicos de uma contradição e a busca de alternativas sustentáveis. São Paulo: Cortez.

43. World Commission on Environment Development. (1991). An overview. Oxford: Universidade de Oxford. 